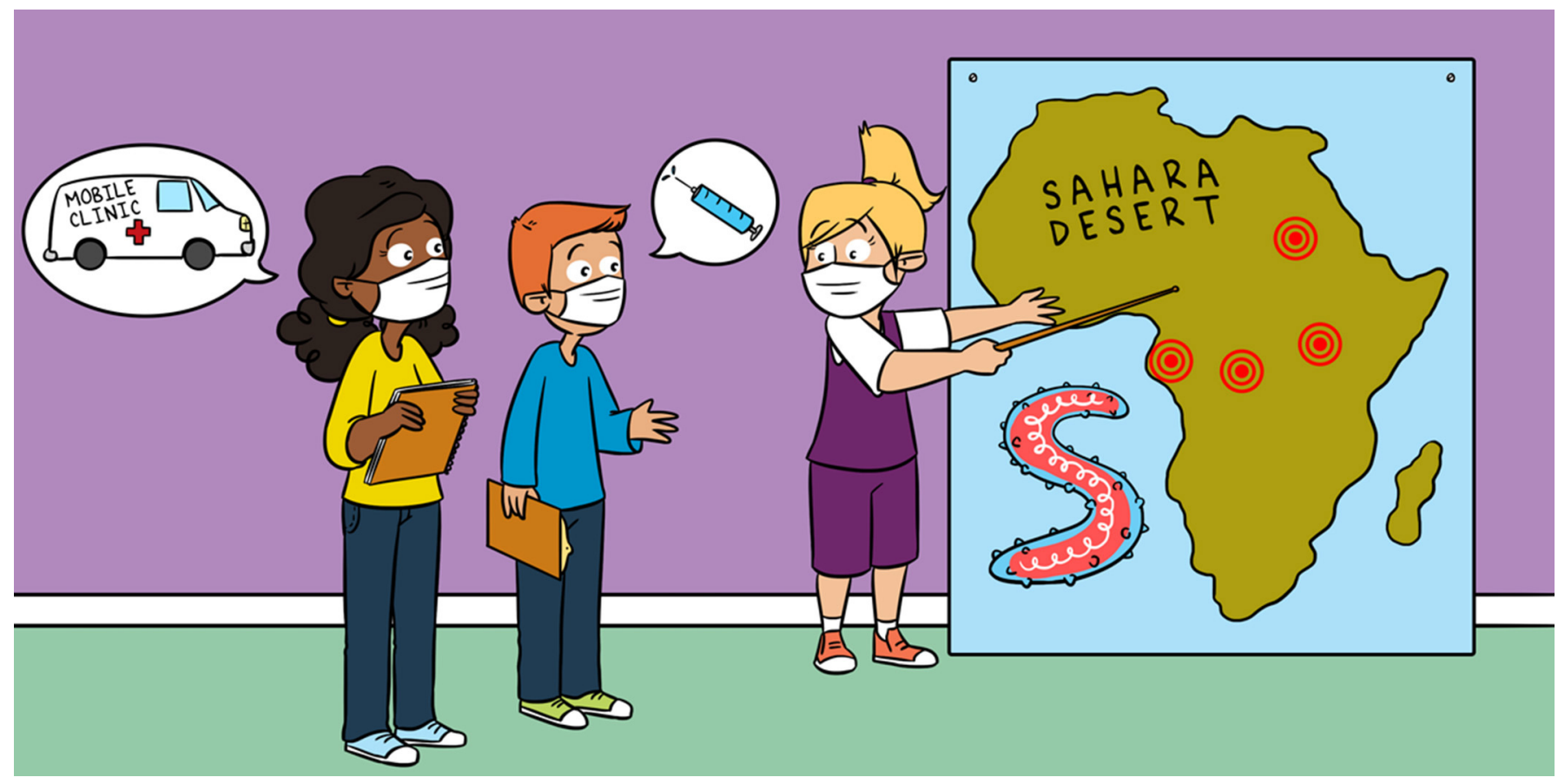

\title{
VACCINES AND ANTIBODIES: WEAPONS IN THE FIGHT AGAINST EBOLA VIRUS
}

\section{Patrice Debré ${ }^{1 *}$, Marie Neunez $^{2,3}$ and Michel Goldman ${ }^{2}$ \\ ${ }^{1}$ Département d'immunologie, APHP, Sorbonne Université, CIMI (INSERM U1135) Hôpital Pitié Salpêtrière, Paris, France \\ ${ }^{2}$ Institute for Interdisciplinary Innovation in Healthcare (I3h), Université libre de Bruxelles, Brussels, Belgium \\ ${ }^{3}$ Grant of the Belgian Kids' Fund for Pediatric Research, Brussels, Belgium}

\section{YOUNG REVIEWER:}

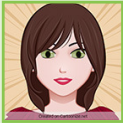

MEHRANEH

AGE: 12
Ebola virus disease is one of the deadliest infections in the world today. The microbe to blame is the Ebola virus. It has already caused numerous outbreaks in Africa, in the regions located south of the Sahara. This article describes the main characteristics of this infectious disease as well as the currently available treatments, namely vaccines and antibodies. Antibodies are produced by the human body when it is infected by a microbe. Antibodies can be collected from the blood of infected humans or animals and purified or manufactured in a laboratory to produce drugs. While vaccines have demonstrated their effectiveness in preventing infectious diseases, antibodies are effective in stopping the progression of several infectious diseases. In this article, you will discover that the stimulation of the immune system, either by the vaccine or by antibodies, is essential to tackle Ebola virus disease. 
Figure 1

Transmission of Ebola virus to humans. Bats can be infected with Ebola virus without getting sick, and they can then spread the virus to other animals or directly to humans. Humans can also contract Ebola by handling sick or infected animals that were previously infected by bats. Infected humans can spread the virus to each other via bodily fluids, including blood, saliva, urine, and vomit.

1 https://en.m. wikipedia.org/ wiki/Sub-

Saharan_Africa

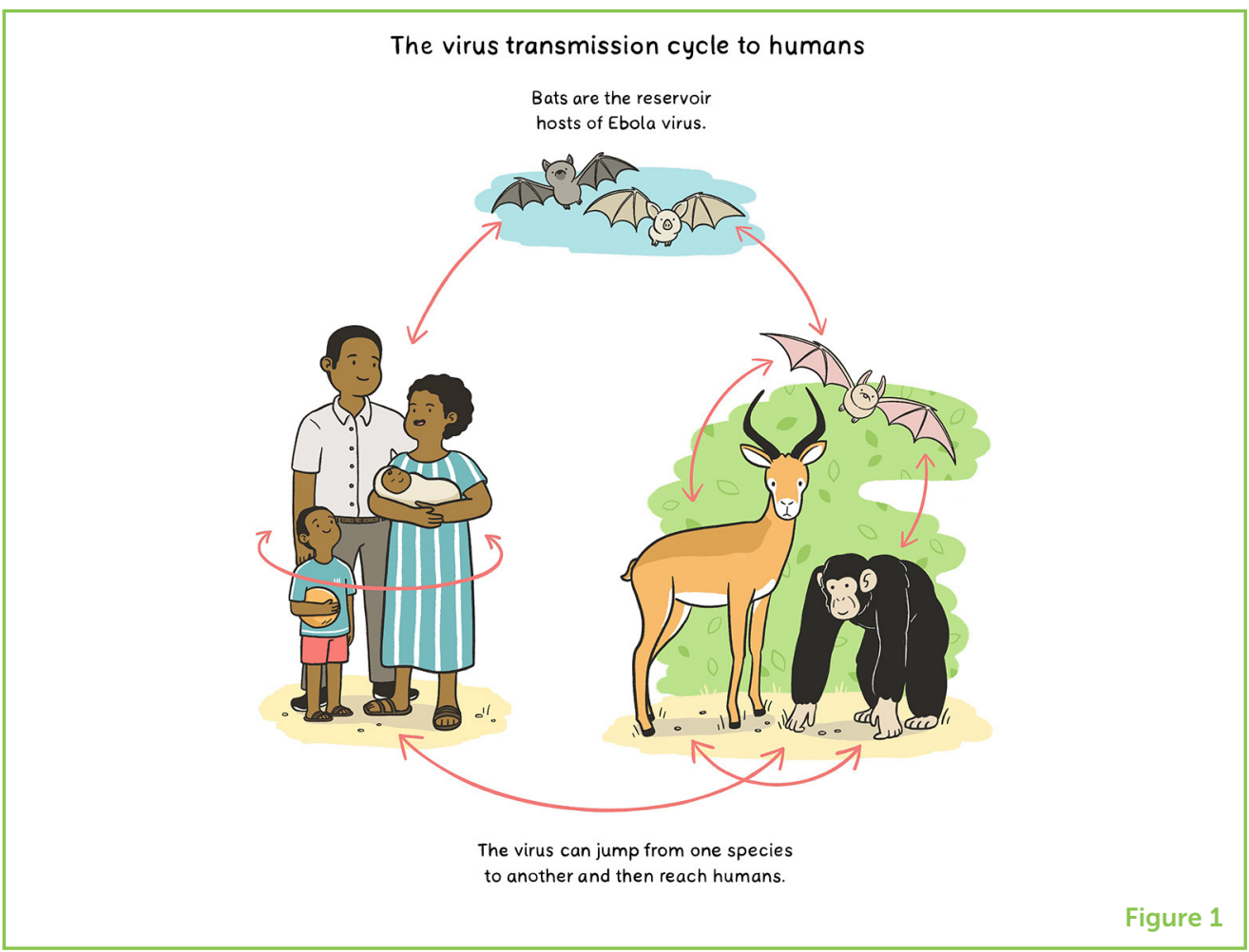

\section{EBOLA VIRUS ORIGIN AND TRANSMISSION TO HUMANS}

Ebola virus was identified for the first time in 1976. Since its discovery, the virus has already caused more than 20 outbreaks in Africa. These outbreaks are quite deadly: it was estimated that if 10 people were infected by the Ebola virus, $<4$ people would survive [1-3]. Ebola virus infections appear in equatorial sub-Saharan Africa ${ }^{1}$, particularly in Sudan, Uganda, Gabon, and the Democratic Republic of Congo. Ebola virus disease originates from animals. Fruit bats naturally harbor Ebola virus, which means that the virus lives inside the bats without harming them. Hence, bats are the natural reservoirs of the Ebola virus. The Ebola virus can jump from bats to other species such as humans and apes (Figure 1).

Ebola virus infections occur when viral particles are absorbed through the mouth, the skin, or through skin wounds. Humans can become infected when handling sick or dead infected animals or by close contact with bats that have the virus. They can also be infected by other humans, for example by contact with blood, saliva, urine, breast milk, semen, sweat, stool, or vomit from infected people. Humans can also be infected through soiled clothing, bedding, gloves, protective equipment, and medical waste, such as syringes. You can see why people need to use extreme caution if they deal with infected patients in hospitals or dead people at funerals. 
Figure 2

The appearance and machinery of Ebola virus. Ebola virus is a filamentous virus, which means it has a worm-like shape. Ebola virus is protected against the environment by its envelope. The viral envelope contains various proteins, including the spike glycoprotein that helps the virus to infect cells.

\section{VIRAL ENVELOPE}

A viral envelope is the outermost layer of many types of viruses. It protects the genetic material in their lifecycle when traveling between host cells.

SPIKE

\section{GLYCOPROTEIN}

a glycoprotein that protrudes from the envelope of some viruses (such as a Ebola or also Coronavirus) and facilitates entry of the virion into a host cell by binding to a receptor on the surface of a host cell.

\section{The appearance and the machinery of Ebola virus.}

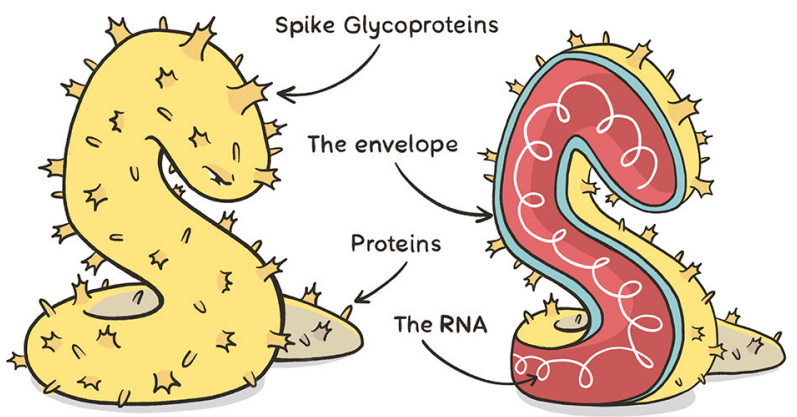

Figure 2

\section{EBOLA VIRUS INFECTION}

Ebola virus has been extensively studied by scientists. Ebola virus is a member of a family of viruses called Filoviridae. Filovirus are filamentous viruses, so named because there are fin and elongated. While the human genome and that of other animals is made of DNA, the genome of Ebola virus is made a related molecule called RNA. The RNA genome and various proteins that help the virus to replicate itself are enclosed within a protective layer called the viral envelope. The envelope has protruding molecules on its surface called spike glycoproteins. The spike glycoproteins help the virus to penetrate and infect cells (Figure 2). If an infection occurs, the immune system of an infected animal will spot these spike glycoproteins and will fight the virus, by calling its immune soldiers onto the field.

Ebola virus disease does not start right away after infection. There is a lag of 2-21 days, called the incubation period, before the replication of the virus causes the first symptoms appear. Ebola virus disease starts with high fever, malaise, fatigue, and body aches. Then gastrointestinal symptoms, such as vomiting and diarrhea, appear, which lead to drastic fluid losses of up to $10 \mathrm{l}$ a day. While some patients recover, others suffer from bleeding and kidney damage, eventually leading to multiple organ failure and death. To diagnose Ebola virus disease, a blood sample is taken from the infected person and examined for the presence of viral particles.

\section{LYMPHOCYTES: THE HEROES OF THE IMMUNE SYSTEM}

Against microbes, and viruses in particular, there are two modes of protection. The first one is to avoid contact with infected people, by respecting a physical distance as proposed for Covid-19. Arthur Semmelweis was the first to promote hand washing back in the 1800s, making hand washing the oldest preventive measure. The French biologist Louis Pasteur, who was afraid of germ transmission, never shook hands. The second type of protection is provided by 


\section{LYMPHOCYTE}

White blood cells that belong to the immune system and protect against dangerous microbes.

\section{ANTIBODY}

A protein produced by $B$ cells of the immune system that specifically detects and neutralizes pathogens.

\section{ANTIGEN}

A foreign substance which induces an immune response.

\section{NEUTRALIZE}

that prevents a virus from replicating.

\section{VACCINATION}

Giving a person or animal a preparation to stimulate the immune system, to protect against infection with a dangerous microbe. the immune system. The immune system defends the body against all types of microbes, using cells and molecules that work together to prevent disease-causing organisms from causing infection. If a microbe succeeds in infecting the body, the immune system will kill the microbe or the infected cells, thanks to the action of its soldiers.

There are two types of immune system soldiers: lymphocytes and antibodies. Lymphocytes are cells that travel through the blood and various tissues. They are activated by microbes and react against them. Some lymphocytes can directly kill infected cells: they are called cytotoxic T cells. Other lymphocytes, called B cells, produce antibodies, which are molecules that circulate in blood and other body fluids. Antibodies recognize specific targets on the surfaces of microorganisms, like the spike glycoproteins of the Ebola virus. Those microbial targets are called antigens. Antibodies neutralize viruses by targeting their antigens. Neutralizing antibodies are very efficient in preventing the spread of viruses from one cell to another.

\section{THE EBOLA VACCINE FOR PREVENTION OF DISEASE}

The best way to prevent people from getting infected with Ebola virus is to vaccinate them against the virus. Vaccination consists of giving a person one or more antigens from the microorganism. These antigens are just parts of the virus and do not cause the disease. Still, the antigens stimulate $B$ cells to make neutralizing antibodies that will circulate in the blood of the vaccinated individual and prepare the immune system to fight the virus more rapidly and efficiently if it is encountered later (Figure 3A). For the Ebola vaccine, the antigen selected is the spike glycoprotein. To produce a vaccine capable of stimulating the immune system and producing neutralizing antibodies, scientists attached the spike glycoprotein to a different, completely harmless virus. The harmless virus carrying the Ebola spike glycoprotein produces large amounts of the Ebola virus spike glycoprotein when it is injected into people. This leads the vaccinated person to produce of high levels of protective neutralizing antibodies against the spike glycoprotein [4].

This Ebola virus vaccine was proven effective in Guinea during an outbreak in west Africa. The vaccine worked well when given as a single shot, and the study indicated that the vaccine could help people to build immunity rapidly. This is good, because it means the vaccine could be used when an Ebola outbreak is first identified, to protect people before they are exposed to the virus. Other vaccine candidates have been proposed, and although they take longer to stimulate immunity, they may provide an immune response that lasts longer. To successfully vaccinate populations at risk of Ebola, some important issues must be addressed. For example, the Ebola virus vaccine must be kept in a cold environment until it is used, which can be difficult 
Figure 3

Fighting Ebola virus infection. (A)

Vaccination can prevent healthy people from getting infected but cannot help when a person is already infected. (B) People who are already sick with an Ebola virus infection can be treated with monoclonal antibodies. When administered into the blood of a sick person, these antibodies can neutralize the virus that is already present and prevent it from spreading between cells.

\section{MONOCLONAL}

\section{ANTIBODIES}

antibodies produced by the same population of lymphocytes,

specifically recognizing the same antigen.

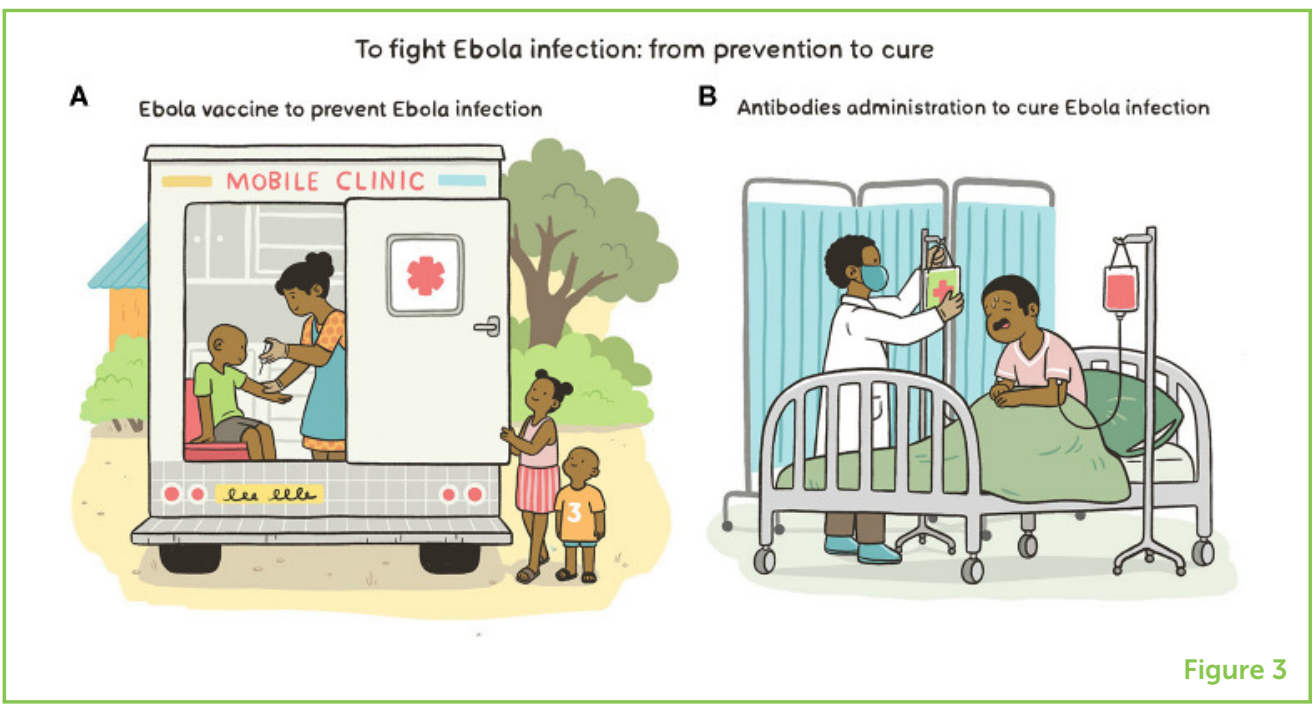

in remote areas. Also, populations must agree to be vaccinated, which is often a huge challenge because a significant percentage of people are frightened by vaccination and do not understand that by vaccinating themselves not only are they protecting themselves but also protecting others from the transmission of the virus.

\section{ADMINISTRATION OF ANTIBODIES FOR TREATMENT OF DISEASE}

If a person is already infected with Ebola virus, there is no time for a vaccine to do its work stimulating the immune system. But neutralizing antibodies from other people or animals can still help! Such antibodies can be injected into an infected person, where they can directly neutralize the virus and decrease its spread from one cell to another (Figure 3B). In the past, these antibodies were obtained from the blood of infected animals or humans. Today, we use antibodies produced in laboratories, which are created to recognize a specific antigen from the virus. These are called monoclonal antibodies [4]. A single monoclonal antibody can be given, or patients might receive a mixture of monoclonal antibodies that recognize different viral antigens.

\section{CONCLUSIONS AND TAKE HOME MESSAGES}

While simple measures, such as hand washing and reducing contact with infected people or animals, are effective in limiting the spread of a virus, stronger measures are often needed. Both the Ebola vaccine and treatment with monoclonal antibodies directed against Ebola virus have been shown to effectively defend humans against Ebola virus disease. This is important because Ebola virus is one of the deadliest infection of the world, through numerous outbreaks in Africa The effectiveness of vaccination and monoclonal antibody 
treatment in fighting Ebola virus disease also shows us the importance of understanding how the immune system reacts to the Ebola virus - or any other dangerous virus. When scientists do laboratory research to understand how the immune system fights against a virus, they can then use this information to come up with treatments that will help to keep people healthy or, in the case of Ebola virus, even save many lives. It remembers us that vaccine does not only protect yourself from infection but also protect others by diminishing the virus spreading.

\section{REFERENCES}

1. Malvy, D., McElroy, A. K., De Clerck, H., Gunther, S., and Van Griensven, J. 2019. Ebola virus disease. Lancet 393:936-48. doi: 10.1016/S0140-6736(18)33132-5

2. Feldmann, H., Sprecher, A., and Geisbert, W. T. 2020. Ebola. N. Engl. J. Med. 382:1832-42. doi: 10.1056/NEJMra1901594

3. Levy, Y., Lane, C., Piot, P., Beavogui, A. H., Kieh, M., Leigh, B., et al. 2018. Prevention of Ebola virus disease through vaccination: where are we in 2018. Lancet 392:787-90. doi: 10.1016/S0140-6736(18)31710-0

4. European Commission. Vaccine Against Ebola: Commission Grants New Market Authorisations. Brussels. 2020. Available online at: https://ec.europa.eu/ commission/presscorner/detail/en/ip_20_1248

SUBMITTED: 11 August 2020; ACCEPTED: 28 June 2021;

PUBLISHED ONLINE: 12 August 2021.

EDITED BY: Kelly Westlake, University of Maryland, United States

CITATION: Debré P, Neunez M and Goldman M (2021) Vaccines and Antibodies: Weapons in the Fight Against Ebola Virus. Front. Young Minds 9:593713. doi: 10. 3389/frym.2021.593713

CONFLICT OF INTEREST: The authors declare that the research was conducted in the absence of any commercial or financial relationships that could be construed as a potential conflict of interest.

COPYRIGHT @ 2021 Debré, Neunez and Goldman. This is an open-access article distributed under the terms of the Creative Commons Attribution License (CC BY). The use, distribution or reproduction in other forums is permitted, provided the original author(s) and the copyright owner(s) are credited and that the original publication in this journal is cited, in accordance with accepted academic practice. No use, distribution or reproduction is permitted which does not comply with these terms. 


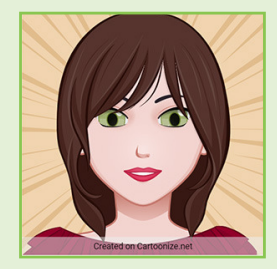

\section{YOUNG REVIEWER}

\section{MEHRANEH, AGE: 12}

$\mathrm{Hi}$, I am Mehraneh (Kinda hard to pronounce) (-) I like to bake, read, shop, and bike. I REALLY like drawing and I am teaching myself using YouTube videos. My Mom is an editor. Then, MAGICALLY, we found this site! And now I get to Really work with mom. YAY ME (and mom)! I love this editing work even more than I thought I would! It is so cool, fun and challenging. I learn so many new things here!

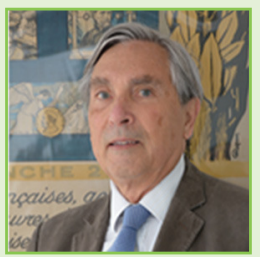

\section{AUTHORS}

\section{PATRICE DEBRÉ}

Emeritus professor of Immunology at Paris Sorbonne University, full member of the French Academy of Medicine, Patrice Debré is former head of the Immunology department of the PITIE-SALPETRIERE Hospital, former director of CNRS and INSERM units and of an Institute of Cancer Immunity and Infection Research. He has held many national administrative responsibilities at Inserm, CNRS, Pierre and Marie Curie University, Assistance Publique Hôpitaux de Paris, Etablissement Français du Sang, Ministry of Research and Higher Education. He was ambassador in charge of the fight against HIV AIDS and communicable diseases at the Ministry for Europe and Foreign Affairs and has exercised many international responsibilities including the presidency of CIRAD (international research center in agronomy for development), and the French representation in many international multilateral organizations (Global Fund, EDCTP, UNITAID, Roll Back Malaria). He is currently an advisor to AVIESAN and to the International Relations Department of APHP. He is a member of the CNRS Ethics Committee and Chairman of the International Relations Committee and of the Biology Commission of the National Academy of Medicine. *patricedebreayahoo.fr

\section{MARIE NEUNEZ}

I am a part-time research fellow at the I3h Institute and Student in Medicine at the Université Libre de Bruxelles (ULB). I was a Clinical Research Coordinator for 2 years in the Departments of Nuclear Medicine \& Radiotherapy at the Institut Jules Bordet (IJB). I also performed a 5-month internship at BASF SE (Mannheim, Germany) in the Human Health $\&$ Nutrition department. I hold a MSc degree in Bioengineering with a specialization in Science, Technology and Quality of Food (UCL, Belgium), a Postgraduate degree in Management (ICHEC Business Management School, Belgium) and a certificate in Clinical Studies (Cefochim, Belgium).

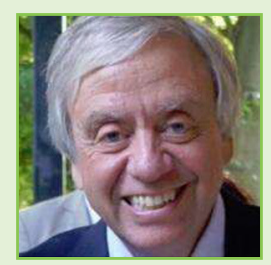

\section{MICHEL GOLDMAN}

Michel Goldman graduated as a Medical Doctor (1978) from the Université libre de Bruxelles (ULB), Belgium, and received his PhD in medical sciences (1981) from the Universite de Genève, Switzerland. From 1990 to 2008, he was the chairman of the Department of Immunology at Erasme Hospital in Brussels, and from 2004 to 2009 he served as the first Director of the Institute for Medical Immunology of ULB. From 2009 to 2014, Michel Goldman served as the first Executive Director of the Innovative Medicines Initiative (IMI) a joint undertaking between the European Commission and the European Federation of Pharmaceutical Industries and Associations. Managing a 
budget of $€ 2$ billion, he was responsible for the launch of 59 public-private consortia in areas of major importance for public health. 